\title{
Editorial
}

\section{Acute airways obstruction in children under 5}

Acute airways obstruction in children under 5 presents a major challenge to the paediatrician and the general practitioner. Wheezing cccurs more frequently in this age group than in any other, ${ }^{2}$ but response to treatment cannot be predicted from information on older children and adults. ${ }^{34}$ Many youngsters are unable to use the inhaler devices that have altered the management of older asthmatic patients so dramatically. In addition, their inability to co-operate in lung function tests has severely limited the collection of data on the pathophysiology of their lung disease as well as the objective assessment of their responses to various treatment regimens. ${ }^{5}$ Only in the last 15 years, with the development of the infant total-body plethysmograph ${ }^{6}$ and the forced oscillation technique, ${ }^{7}$ have we begun to obtain information on wheezy preschool children. ${ }^{148}$ Under the age of 3 years the need for prior sedation with chloral hydrate has limited studies to those who are no longer critically ill $^{10}$ and has meant that the results may be to some extent distorted by the sedation.

\section{Nature of acute airways obstruction in the very young}

Young children with airways obstruction can be divided into two groups. The first includes all those with recurrent attacks of coughing and wheezing. Because these attacks frequently follow viral upper respiratory tract infections ${ }^{11}$ they are sometimes labelled "chest infection," "bronchitis," "wheezy bronchitis," or "wheezing-associated respiratory illness," rather than asthma. From the epidemiological point of view, however, such children are indistinguishable from the older asthmatic population and they can be regarded as at one end of the asthma spectrum. ${ }^{12} \mathrm{~s}^{14}$ They also have labile airways, as shown by changes in airways obstruction after $\beta_{2}$ stimulants, ${ }^{34}$ ipratropium bromide,${ }^{410}$ exercise,${ }^{8}$ and inhaled histamine..$^{15}$ Although allergen skin tests may give positive results ${ }^{16}$ and serum IgE and eosinophil counts be raised, ${ }^{17}$ allergic triggers for wheezing are far less evident clinically than in some older asthmatic patients. ${ }^{18}$

The second category of children with airways obstruction is those with acute bronchiolitis. The typical clinical picture is of an infant 1-8 months, without any past history of wheezing, who develops rhinorrhoea, an irritating cough, distressed rapid breathing, and difficulty in feeding. On examination, there is hyperinflation of the lungs, and fine crepitations are heard throughout both lung fields (with or without a high-pitched wheeze). Bronchiolitis occurs in epidemics in the winter months and is predominantly due to respiratory syncytial virus infection, ${ }^{19}$ although many other viruses, including parainfluenza virus and adenovirus, can cause a similar picture. ${ }^{2021}$ Inevitably bronchiolitis and asthma merge with each other and the picture is complicated by the observation that over half the children who have had respiratory syncytial virus bronchiolitis subsequently experience recurrent attacks of coughing and wheezing. ${ }^{22} 23$

\section{Natural history and prognosis}

Long-term prospective studies of general populations are limited, but about $70 \%$ of asthma in childhood and $30 \%$ in adults starts in the first five years of life. ${ }^{122-27}$ Although this would suggest that the prognosis for preschool wheezing is poor, clinical impression is that many children "grow out" of their symptoms. Epidemiological evidence provides some support for this optimistic view, but many children whose asthma remits during adolescence suffer a relapse. ${ }^{25} 27$ About half of those who wheeze in early childhood are wheeze free 15-20 years later, and most of those with continuing asthma have some amelioration in symptoms. ${ }^{25} 27$

Many of the children who have wheezing attacks after viral bronchiolitis have grown out of their symptoms by the time they start school. ${ }^{23} 28 \mathrm{~A}$ recent follow-up study from Newcastle upon Tyne on children with well-documented respiratory syncytial virus bronchiolitis suggests that atopy does not predispose to postbronchiolitic wheezing ${ }^{28}{ }^{29}$ Although the children had bronchial hyperreactivity, the prevalence of positive responses to allergen skin tests, raised serum IgE concentrations, and eosinophilia was similar to that in controls. We still do not know whether the airways were abnormal before respiratory syncytial virus infection, resulting in a severe attack necessitating hospital admission, or whether the infection itself had increased bronchial reactivity, as with the changes seen in adults with upper respiratory tract infection. ${ }^{30}$ The Newcastle study found that the frequency of wheezing in relatives of 
index children and controls was the same,$^{28}$ which is further support for the hypothesis that the virus is responsible for the abnormal airway lability.

Acute bronchiolitis rarely may lead to severe, persisting small airway damage that produces irreversible airway obstruction. This is particularly likely with adenovirus types 3,7 , and 21 but is occasionally seen after respiratory syncytial virus infections. ${ }^{2131} \mathrm{~A}$ worrying observation is the finding of abnormalities in blood gases and results of lung function tests in a follow-up study of 23 children who had been symptom free for 10 years after bronchiolitis in infancy. ${ }^{32}$ The abnormalities were consistent with obstruction of the small airways or loss of elastic recoil and were not thought to be due to asthma. Recent prospective data on lung volumes also suggest that acute bronchiolitis may produce long-lasting damage that is not entirely due to abnormal airway lability. ${ }^{33}$ This and other epidemiological evidence ${ }^{3435}$ suggests that acute bronchiolitis in infancy could be an important factor in the pathogenesis of chronic bronchitis and emphysema in the adult.

\section{Management}

The most important aspect of management, and one that is frequently neglected, is providing the parents with information and explanation. For children less than 18 months of age we have little to offer in the way of drug treatment. Many studies in children under 12 months have failed to show any improvement in lung function after salbutamol, ${ }^{36}$ isoprenaline ${ }^{36}$ orciprenaline, ${ }^{9}$ phenylephrine, ${ }^{37}$ or adrenaline. ${ }^{37}$ The age at which responsiveness to $\beta_{2}$-stimulants is gained is around 18 months, ${ }^{3}$ although the occasional child will respond well before this. The reason for this resistance to sympathomimetics remains obscure. It has been suggested that bronchial and bronchiolar muscle is poorly developed in infants and that mucosal oedema and mucous hypersecretion are responsible for the airways obstruction. ${ }^{9}$ Bronchial wall smooth muscle is, however, present in children less than 18 months old ${ }^{38}$ Furthermore, even the preterm neonate will develop tachycardia after receiving theophylline or salbutamol, ${ }^{39}$ indicating that $\beta$-receptors are active at least in the heart. Mucosal oedema and secretions may be of greater significance than at later ages, but the total lack of response remains surprising. Even systemic corticosteroids seem to lose their antiasthma potency in the first six to eight months of life. At present we have scanty information on the efficacy of sodium cromoglycate at this age, although clinical experience suggests it may be of benefit. Unexpectedly, ipratropium bromide, an anticholinergic drug, is effective in reducing airways obstruction in the laboratory in $40 \%$ of wheezy babies under 18 months of age.$^{10} \mathrm{It}$ is too early to state whether it will be a clinically useful drug in this age group.

For wheezy children over 18 months of age, the main therapeutic problem is the mode of drug delivery. Most have relatively mild and infrequent attacks that respond to intermittent oral $\beta_{2-}$ stimulants, with useful but not total bronchodilatation after $30-60$ minutes. ${ }^{40}$ Those with more persistent symptoms may be helped by regular sympathomimetic treatment, alone or in combination with regular theophylline. The unpleasant taste of theophyllines has limited their popularity outside North America; but a slow-release preparation in the form of minispheres supplied in capsules is now available. The contents can be tipped on to a spoon and fed to the youngster on a suitably appetising "bribe."

Those whose asthma is still not adequately controlled will require sodium cromoglycate. Since the very young child is unable to use a spinhaler, a compressor and nebuliser system must be acquired for use at home. ${ }^{41}$ During an acute attack of asthma nebulised salbutamol or terbutaline can be administered. This has proved a dramatically effective form of treatment, greatly reducing the need for admissions to hospital and courses of systemic steroids. Unfortunately the cost of nebuliser systems, although much less than admissions to hospital, has limited their use. By the age of 4 years many children can be weaned on to salbutamol inhaled as dry powder (Rotacaps) ${ }^{42}$ or terbutaline with a spacer attachment. Beclomethasone is also available in powder form and has proved highly effective in children down to the age of 3 . But it is important to realise that a 4-year-old who can use these devices when he is well will not be able to do so when he is acutely distressed and wheezing.

As might be predicted from the above, the management of acute bronchiolitis remains a problem. The work of breathing can now be measured in acutely ill infants without the need for sedation, by using a nasogastric tube to measure oesophageal pressure and an inflatable rubber jacket encompassing the chest and abdomen to measure change in thoracic volume.$^{43}$ Using this system we have shown that, as with recurrent wheezing in the first year of $\omega$ life, neither nebulised water nor salbutamol produces any benefit, and that a small but definite 0 improvement is seen after nebulised ipratropium bromide (unpublished observation). Large clinical ? studies have failed to show any relief with theophylline or steroids..$^{44-46}$ Effective treatment is limited to giving oxygen for hypoxia, maintaining hydration, monitoring, and nursing care. 


\section{Prevention of asthma}

Much has been written about the possibility of preventing asthma by exclusively breast-feeding babies for at least the first six months of life. This idea received a major boost when it was reported that a transient $\operatorname{IgA}$ deficiency at about 3 months of age was associated with the development of eczema and positive skin test responses within the first year. ${ }^{47}$ The hypothesis was that during this vulnerable period antigens could more easily cross the gut mucosa and that allergen avoidance during this time might prevent much atopic disease. A prospective study did indeed show a tendency to develop eczema in babies fed cows' milk. ${ }^{48}$ The group concerned has been unable, however, to repeat the initial IgA results. Recently numerous studies, including an epidemiological one that carefully controlled factors other than method of feeding, have failed to show any protective effect from breast-feeding. ${ }^{4-51}$ The issue is still unresolved because another recent report suggests that breast-feeding may provide some protection against the development of asthma.$^{53}$ There is anecdotal evidence that the occasional wheezy infant improves dramatically when given a diet free from cows' milk. Investigators trying to identify these children in their own community, however, have found that wheezing is an unusual manifestation of intolerance to cows' milk protein and that when it does occur it is usually associated with eczema and diarrhoea. ${ }^{53}$

It has been reported that breast-feeding may offer some protection against respiratory syncytial virus infection in infancy, ${ }^{54}$ although in the original study it was not possible to correct for all other variables. An effective vaccine against respiratory syncytial virus would obviously be of considerable value. Despite vigorous attempts, neither live nor inactivated respiratory syncytial virus vaccines have been efficacious in protecting against natural infection. ${ }^{55}$

The environmental factor that is most likely to alter the risk of wheezing in infancy is passive smoking. The association between maternal smoking and infantile lower respiratory tract illness is strong and people in regular and prolonged contact with infants should not smoke. ${ }^{56}$

Wheezing in the very young, particularly those under the age of 18 months, remains a frustrating problem that urgently needs more attention. In particular, we need to discover why these toddlers are so unresponsive to the drugs that work well in the older child, and thereby find effective remedies. The association between wheezing in these children and asthma in later life, and possibly between acute bronchiolitis and subsequent chronic bronchitis in adult life, provides a major and exciting challenge.
Effective care of these children might have a dramatic effect on the incidence of adult respiratory disease.

AD MILNER
RL HENRY
Department of Child Health,
University Hospital,
Nottingham

\section{References}

' Henderson FW, Clyde WA, Collier AM, et al. The etiologic and epidemiologic spectrum of bronchiolitis in pediatric practice. $J$ Pediatr 1979;95:183-90.

${ }^{2}$ Gregg I. Infection. In: Clark TJH, Godfrey S, eds. Asthma. London: Chapman and Hall, 1977:162-76.

${ }^{3}$ Lenney W, Milner AD. At what age do bronchodilator drugs work? Arch Dis Child 1978;53:532-5.

${ }^{4}$ Groggins RC, Milner AD, Stokes GM. Bronchodilator effects of clemastine, ipratropium bromide, and salbutamol in preschool children with asthma. Arch Dis Child 1981;56:342-4.

${ }^{5}$ Polgar G, Weng TR. State of the art. The functional development of the respiratory system from the period of gestation to adulthood. Am Rev Respir Dis 1979;120:625-95.

- DuBois AB, Botelho SY, Comroe JH. A new method for measuring airway resistance in man using a body plethysmograph: values in normal subjects and in patients with respiratory disease. J Clin Invest 1956;35:327-35.

7 Cogswell JJ. Forced oscillation technique for determination of resistance to breathing in children. Arch Dis Child 1973;48:259-66.

${ }^{8}$ Lenney W, Milner AD. Recurrent wheezing in the preschool child. Arch Dis Child 1978;53:468-73.

- Phelan PD, Williams HE. Studies of respiratory function in infants with recurrent asthmatic bronchitis. Aust Paed J 1969;5:187-96.

${ }^{10}$ Hodges IGC, Groggins RC, Milner AD, Stokes GM. Bronchodilator effect of inhaled ipratropium bromide in wheezy toddlers. Arch Dis Child 1981;56:729-32.

"Horn MEC, Brain EA, Gregg I, Inglis JM, Yealland SJ, Taylor P. Respiratory viral infection and wheezy bronchitis in childhood. Thorax 1979;34:23-8.

12 Williams H, McNicol KN. Prevalence, natural history, and relationship of wheezy bronchitis and asthma in children. An epidemiological study. Br Med J 1969;iv:321-5.

${ }^{13}$ Sibbald B, Horn MEC, Gregg I. A family study of the genetic basis of asthma and wheezy bronchitis. Arch Dis Child 1980;55:354-7.

${ }^{14}$ Konig P, Godfrey S. Exercise-induced bronchial liability and atopic status of families of infants with wheezy bronchitis. Arch Dis Child 1973;48:942-6.

15 Henry RL, Mellis CM, South RT, Simpson SJ. Comparison of peak expiratory flow rate and forced expiratory volume in one second in histamine challenge studies in children. Br J Dis Chest 1982;76:167-70. 
16 Van Asperen PP, Mellis CM, South RT, Simpson SJ. Allergen skin-prick testing in asthmatic children. Med J Aust 1980;ii:266-8.

${ }^{17}$ Foucard T. A follow-up study of children with asthmatoid bronchitis. Acta Paed Scand 1974;63:129-39.

${ }^{18}$ Landau LI. Outpatient evaluation and management of asthma. Paediatr Clin North Am 1979;26:581-601.

19 Report to the Medical Research Council Subcommittee on Respiratory Syncytial Virus Vaccines. Respiratory syncytial virus infection: admissions to hospital in industrial, urban, and rural areas. $\mathrm{Br}$ Med $J$ 1978;ii:796-8.

${ }^{20}$ Williams HE, Phelan PD. Respiratory illness in children. Oxford: Blackwell, 1975.

${ }^{21}$ Lang WR, Howden CW, Laws J, Burton JF. Bronchopneumonia with serious sequelae in children with evidence of adenovirus type 21 infection. $\mathrm{Br} \mathrm{Med} J$ 1969;i:73-9.

${ }^{22}$ Rooney JC, Williams HE. The relationship between proved viral bronchiolitis and subsequent wheezing. $J$ Pediatr 1971;79:744-7.

${ }^{23}$ Eisen AH, Bacal HL. The relationship of acute bronchiolitis to bronchial asthma-a 4-to-14 year followup. Pediatrics 1963;31:859-60.

${ }^{24}$ Gregg I. Epidemiology. In: Clark TJH, Godfrey S, eds. Asthma. London: Chapman and Hall, 1977:214-40.

${ }^{25}$ Blair H. Natural history of childhood asthma. Arch Dis Child 1977;52:613-9.

${ }^{26} \mathrm{McNicol} \mathrm{KN}$, Williams HE. Spectrum of asthma in children. I Clinical and physiological components. $\mathrm{Br}$ Med J 1973;iv:7-11.

${ }^{27}$ Martin AJ, McLennan LA, Landau LI, Phelan PD. The natural history of childhood asthma to adult life. $\mathrm{Br}$ Med J 1980;280:1397-400.

${ }^{28}$ Pullan CR, Hey EN. Wheezing, asthma, and pulmonary dysfunction 10 years after infection with respiratory syncytial virus in infancy. Br Med J 1982;284:1665-9.

${ }^{29}$ Sims DG, Gardner PS, Weightman D, Turner MW, Soothill JF. Atopy does not predispose to RSV bronchiolitis or postbronchiolitic wheezing. $\mathrm{Br} \mathrm{Med} J$ 1981;282:2086-8.

${ }^{30}$ Empey DW, Laitinen LA, Jacobs L, Gold WM, Nadel JA. Mechansims of bronchial hyperreactivity in normal subjects after upper respiratory tract infecton. $A m$ Rev Respir Dis 1976;113:131-9.

${ }^{31}$ Hodges IGC, Milner AD, Groggins RC, Stokes GM. Causes and management of bronchiolitis with chronic obstructive features. Arch Dis Child 1982;57:495-9.

${ }^{32}$ Kattan M, Keens TG, Lapierre J, Levison H, Bryan AC, Reilly BJ. Pulmonary function abnormalities in symptom-free children after bronchiolitis. Pediatrics 1977;59:683-8.

${ }^{33}$ Stokes GM, Milner AD, Hodges IGC, Groggins RC. Lung function abnormalities after acute bronchiolitis. J Pediatr 1981;98:871-4.

${ }^{34}$ Colley JRT, Douglas JWB, Reid DD. Respiratory disease in young adults: influence of early childhood lower respiratory tract illness, social class, air pollution, and smoking. Br Med J 1973;iii: 195-8.

${ }^{35}$ Burrows B, Knudson RJ, Lebowitz MD. The relationship of childhood respiratory illness to adult obstructive airway disease. Am Rev Respir Dis
1977;115:751-60.

${ }^{36}$ Rutter N, Milner AD, Hiller EJ. Effects of bronchodilators on respiratory resistance in infants and young children with bronchiolitis and wheezy bronchitis. Arch Dis Child 1975;50:719-22.

${ }^{37}$ Lenney W, Milner AD. Alpha and beta adrenergic stimulants in bronchiolitis and wheezy bronchitis in children under 18 months of age. Arch Dis Child 1978;53:707-9.

${ }^{38}$ Matsuba K, Thurlbeck WM. A morphometric study of bronchial and bronchiolar walls in children. Am Rev Respir Dis 1972;105:908-13.

${ }^{39}$ Kuzemko JA, Paala J. Apnoeic attacks in the newborn treated with aminophylline. Arch Dis Child 1973;48:404-6.

${ }^{40}$ Groggins RC, Lenney W, Milner AD, Stokes GM Efficacy of orally administered salbutamol and theophylline in preschool children with asthma. Arch Dis Child 1980;55:204-6.

${ }^{41}$ Hiller EJ, Milner AD, Lenney W. Nebulised sodium cromoglycate in young asthmatic children. Arch Dis Child 1977;52:875-6.

${ }^{42}$ Lenney W, Milner AD, Hiller EJ. Use of salbutamol powder in childhood asthma. Arch Dis Child 1978;53:958-61.

${ }^{43}$ Stokes GM, Milner AD, Groggins RC. Work of breathing, intra-thoracic pressure and clinical findings in a group of babies with bronchiolitis. Acta Paed Scand 1981;70:689-94.

44 Brooks LJ, Bropp GJA. Theophylline therapy in bronchiolitis. Am J Dis Child 1981;135:934-6.

${ }^{45}$ Connolly JH, Field CMB, Glasgow JFT, Slattery CM, MacLynn DM. A double blind trial of prednisolone in epidemic bronchiolitis due to respiratory syncytial virus. Acta Paed Scand 1969;58:116-20.

${ }^{46}$ Leer JA, Bloomfield NJ, Green JL, et al. Corticosteroid treatment in bronchiolitis. Am J Dis Child 1969;117:495-503.

${ }^{47}$ Taylor B, Norman AP, Orgel HA, Stokes CR, Turner MW, Soothill JF. Transient IgA deficiency and pathogenesis of infantile atopy. Lancet 1973;ii:111-3.

${ }^{48}$ Matthew DJ, Taylor B, Norman AP, Turner MW, Soothill JF. Prevention of eczema. Lancet 1977;i:321-4.

49 Golding J, Butler NR, Taylor B. Breast-feeding and eczema/asthma. Lancet 1982;i:623.

${ }^{50}$ Cogswell JJ, Alexander J. Breast-feeding and eczema/ asthma. Lancet 1982;i:910.

51 Gordon RR, Noble DA, Ward AM, Allen R. Immunoglobulin $\mathrm{E}$ and the eczema/asthma syndrome in early childhood. Lancet 1982;i:72-4.

s2 Hide DW, Guyer BM. Clinical manifestations of allergy related to breast and cow's milk feeding. Arch Dis Child 1981;56:172-5.

53 Jakobsson I, Lindberg T. A prospective study of cow's milk protein intolerance in Swedish infants. Acta Paed Scand 1979;68:853-9.

${ }^{54}$ Downham MAPS, Scott R, Sims DG, Webb JKG, Gardner PS. Breast-feeding protects against respiratory syncytial virus infections. $\mathrm{Br}$ Med J 1976;ii:274-6.

ss Belshe RB, Van Voris LP, Mufson MA. Parenteral administration of live respiratory syncytial virus vac- 
cine: results of a field trial. $J$ Infect Dis 1982;145:311-9.

${ }^{56}$ Fergusson DM, Harwood LJ, Shannon FT. Parental smoking and respiratory illness in infancy. Arch Dis Child 1980;55:358-61. 